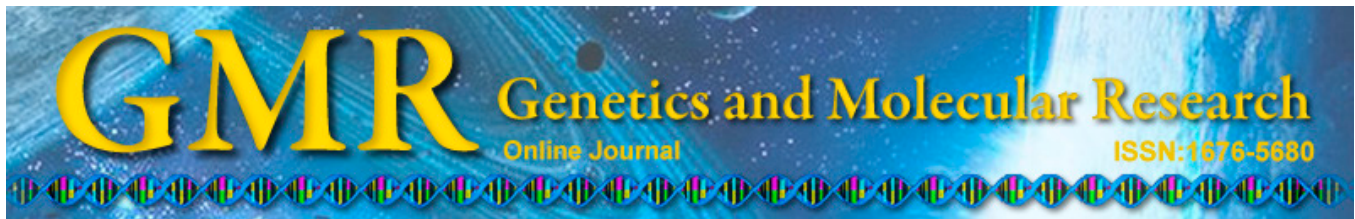

\title{
Influence of gossypol acetic acid on the growth of human adenoid cystic carcinoma ACC-M cells and the expression of DNA methyltransferase 1
}

\author{
Y. Wu, Y.-N. Wei, W.-Y. Yue, W.-F. Chen and S. Fu \\ Oral and Maxillofacial Surgery, \\ Affiliated Stomatology Hospital of Kunming Medical University, \\ Kunming Yunnan, China \\ Corresponding author: $\mathrm{Y}$. Wu \\ E-mail:wuyong_1@163.com
}

Genet. Mol. Res. 14 (4): 13456-13466 (2015)

Received June 8, 2015

Accepted September 25, 2015

Published October 28, 2015

DOI http://dx.doi.org/10.4238/2015.October.28.6

ABSTRACT. We investigated the effects of gossypol acetic acid
(GAA) on the proliferation, apoptosis, and expression of DNA
methyltransferase 1 (DNMT1) mRNA in human adenoid cystic
carcinoma (ACC-M) cells in vitro. The proliferation and apoptosis
of ACC-M cells after treatment with different concentrations of
GAA were detected using Cell Counting Kit- 8 and flow cytometry,
respectively. DNMT1 mRNA expression was measured by real-time
fluorescence quantitative polymerase chain reaction. The growth of
ACC-M cells was inhibited after treatment with GAA for 24, 48 , and
$72 \mathrm{~h}$. The apoptotic rates of ACC-M cells after treatment with GAA
for $72 \mathrm{~h}$ were higher than those of control cells (without treatment) (P
$<0.05$ ). DNMT1 mRNA expression in ACC-M after treatment with
GAA for $72 \mathrm{~h}$ was lower than that in control cells (P $<0.05$ ). GAA
had inhibitory effects on the proliferation and induced apoptosis of 
human ACC-M cells, while GAA also reduced the expression level of DNMT1 mRNA in ACC-M cells.

Key words: Adenoid cystic carcinoma cells; Gossypol acetic acid; Methyltransferases

\section{INTRODUCTION}

Gossypol, which is extracted from cotton seed oil, is commonly used medically as gossypol acetic acid (GAA), a male contraceptive. Previous studies found that gossypol and its derivatives could inhibit the proliferation of nasopharyngeal carcinoma cells and other head and neck squamous cell carcinoma (HNSCC) cells, induce the apoptosis of tumor cells with high expression of $\mathrm{Bcl}-2 / \mathrm{Bcl}-\mathrm{xL}$, and significantly inhibit the growth of colon and nasopharyngeal carcinoma xenograft tumors in nude mice (Zhang et al., 2003; Oliver et al., 2004; Hu et al., 2008). HNSCC cells were inoculated into nude mice by Wolter et al. (2006), and it was found that the growth of tumors treated with gossypol was significantly inhibited and showed higher mortality than the control group. DNA methyltransferase 1 (DNMT1) is a key enzyme that maintains the methylation state of DNA. Several studies found that high expression of DNMT1 improved the methylated modification rate of tumor suppressor genes in tumor tissues, resulting in silencing of this gene and an increase tumor malignant degree (Peng et al., 2006; Agoston et al., 2007). DNMT1 expression level can also regulate the cell cycle, which can induce the entrance into $\mathrm{S}$ phase and regulate cell growth and proliferation (Milutinovic et al., 2003). In our prophase research (Yue et al., 2014a,b), we found that GAA decreased the methylation degree of related tumor suppressor genes in adenoid cystic carcinoma (ACC-M) cells, but it was unclear whether this resulted from decreased expression of DNMT1 after GAA treatment. To investigate the relationship between the effects of GAA on ACC-M cells and the expression level of DNMT1 mRNA, we examined the possible antitumor mechanism of gossypol by detecting the growth and apoptosis of ACC-M cells and expression level of DNMT1 mRNA after treatment with GAA.

\section{MATERIAL AND METHODS}

\section{Materials}

Human highly metastatic ACC-M cells and the human lung fibroblast cell line HFL1 were obtained from Shanghai Hufeng Biological Technology Co., Ltd. (Shanghai, China) and Shanghai Bioleaf Biotech Co., Ltd. (Shanghai, China). RPMI 1640 medium, fetal calf serum, dimethyl sulfoxide (DMSO), penicillin G, and streptomycin were purchased from Beijing Solarbio Science \& Technology Co., Ltd. (Beijing, China). GAA (WM 578.61, purity 95\%, dissolved in DMSO) and MTT were purchased from Sigma (St. Louis, MO, USA). The Apoptosis Detection Kit and Reverse Transcription Kit were purchased from Beijing 4A Biotech Co., Ltd. (Beijing, China). Cell Counting Kit-8 (CCK-8) was purchased from the Beyotime Institute of Biotechnology (Beijing, China). TRIzol and SYBR Green PCR Master Mix were purchased from Takara (Shiga, Japan). Primers for DNMT1 were designed and synthesized by Nanjing Zoonbio Biotechnology Co., Ltd. (Nanjing, China). 


\section{Methods}

\section{Cell culture}

ACC-M and HFL-1 cells were cultured in RPMI 1640 containing $10 \%$ fetal bovine serum, $100 \mathrm{U} / \mathrm{L}$ penicillin $\mathrm{G}$, and $100 \mathrm{mg} / \mathrm{mL}$ streptomycin. Cells were maintained at $37^{\circ} \mathrm{C}$ in a humidified atmosphere of $5 \% \mathrm{CO}_{2} / 95 \%$ air and passaged every $2-3$ days.

\section{Influence of GAA on growth of ACC-M and HFL-1 cells detected by CCK-8 method}

Cells were seeded on 96-well plates at a density of $6 \times 10^{4}$ cells/well, with 3 replicates per group. Cells were cultured in a humidified $5 \% \mathrm{CO}_{2}$ atmosphere at $37^{\circ} \mathrm{C}$ for $12 \mathrm{~h}$. The medium was removed and $200 \mu \mathrm{L}$ different concentrations of GAA $(10,20,30,40$, and 50 $\mu \mathrm{M})$ were added to the experimental groups, while RPMI 1640 containing $0.1 \%$ DMSO was added to the control group; the blank control group contained RPMI 1640. We used 3 replicates per group. Cells were cultured for 24,48 , and $72 \mathrm{~h}$. Next, $20 \mu \mathrm{L}$ CCK-8 was added to each well and cultured for $4 \mathrm{~h}$. Finally, absorbance was measured at $450 \mathrm{~nm}$ using an enzymelinked immunosorbent assay instrument. The inhibition rate and 50\% inhibitory concentration $\left(\mathrm{IC}_{50}\right)$ value were calculated separately [inhibitor rate $(\%)=($ average $\mathrm{D}$ value in control group - average $\mathrm{D}$ value in experimental group) / average $\mathrm{D}$ value in control group]. The $\mathrm{IC}_{50}$ values of ACC-M and HFL-1 cells, which were treated with different concentrations of GAA for 24-72 h, were calculated using the linear regression fitting method. Experiments were repeated 3 times.

Influence of GAA on apoptosis of ACC-M cells detected by double-staining with annexin V-fluorescein isothiocyanate (FITC)/propidium iodide (PI) and fluorescence correlation microscopy analysis

The concentration of ACC-M cells in the logarithmic growth phase was adjusted to 2 x $10^{5}$ cells $/ \mathrm{mL}$ and seeded into culture bottles. Different concentrations of GAA $(10,20,30$, 40 , and $50 \mu \mathrm{M}$ ) were added to the bottles when the cells had attached completely. RPMI 1640 was added to the control group and cells were cultured for $72 \mathrm{~h}$. Next, cells were obtained after washing twice with phosphate-buffered saline, and the supernatant was discarded. Cell apoptosis was detected according to the manufacturer instructions for the Apoptosis Detection Kit. A total of 10,000 cells were collected from each group. The excitation wavelength of flow cytometry was $488 \mathrm{~nm}$, the detection wavelength of FITC was $515 \mathrm{~nm}$, and that of PI was 560 $\mathrm{nm}$. Experiments were repeated 3 times.

\section{Influence of GAA on DNMT1 mRNA expression in ACC-M cells detected by real-time fluorescence quantitative polymerase chain reaction (PCR)}

The concentration of ACC-M cells in the logarithmic growth phase was adjusted to $6 \times 10^{4}$ cells $/ \mathrm{mL}$ and the cells were then seeded on 96 -well plates at $100 \mu \mathrm{L} /$ well. The cells were cultured for $12 \mathrm{~h}$. The medium was discarded and $200 \mu \mathrm{L}$ RPMI 1640 medium at different concentrations of $\operatorname{GAA}(0,5,10,15,20,25$, and $30 \mu \mathrm{M})$ was added to the experimental groups, while RPMI 1640 containing $0.1 \%$ DMSO was added to the control 
group, with 3 replicates per group. Cells were collected after $72 \mathrm{~h}$, and total RNA from each group was extracted using TRIzol. Total RNA was subjected to cDNA synthesis using a ReverTra Kit (TaKaRa). PCR and fluorescence detection were conducted in a 7900HT qPCR system thermal cycler, in which the reverse transcription products were used as the template and added to the SYBR Green PCR Master Mix. PCR was conducted using the following primers for DNMT1: forward primer, 5'-CTCCTCTAACTTCACCTCTAT-3'; and reverse primer, 5'-CTGACAACAGCCCATAAC-3'. The primers for $\beta$-actin were as follows: forward primer, 5'-CATTCCAAATATGAGATGCGTTGT-3'; reverse primer, 5'-TGTGGACTTGGGAGAGGACT-3'. PCR conditions were: 5 min denaturation at $94^{\circ} \mathrm{C}$, followed by 442 -step cycles: $35 \mathrm{~s}$ at $94^{\circ} \mathrm{C}, 30 \mathrm{~s}$ at $55^{\circ} \mathrm{C}$, and $35 \mathrm{~s}$ at $72^{\circ} \mathrm{C}$, and renaturation for $8 \mathrm{~min}$ at $72^{\circ} \mathrm{C}$. The melting curve was from $70^{\circ}-90^{\circ} \mathrm{C}$, and the fluorescence signal was read once per $0.3^{\circ} \mathrm{C}$ for $0.1 \mathrm{~s}$. The average $\mathrm{Ct}$ value of DNMT1 and $\beta$-actin was selected, and the different multiple was represented by $2^{-\Delta \Delta C t}\left[\Delta C t=\Delta C t_{\text {experimental group }}-\Delta C t_{\text {control group }}=\left(C t_{\text {DNMT1 in }}\right.\right.$ experimental group $\left.\left.-C t_{\beta \text {-actin in experimental group }}\right)-\left(C t_{\text {DNMT1 in control group }}-C t_{\beta \text {-actin in control group }}\right)\right]$. Values of $2^{-\Delta \Delta C t}>$ 1 indicated that the expression of the target gene was unregulated, while $2^{-\Delta \Delta \mathrm{Ct}}<1$ indicated down-regulation. The experiments were repeated 3 times.

\section{Statistical analysis}

Statistical analysis was performed using the SPSS version 17.0 software (SPSS, Inc., Chicago, IL, USA). Data are reported as means $\pm \mathrm{SD}$. One-way analysis of variance was used to compare groups. The paired comparison used the S-N-K (q) method. Differences of P $\leq$ 0.05 were considered to be statistically significant.

\section{RESULTS}

\section{Proliferation of ACC-M cells inhibited by GAA}

CCK-8 results revealed a statistically significant effect of inhibition rate on the proliferation of ACC-M and HFL-1 cells treated with different concentrations of GAA for 24,48 , and $72 \mathrm{~h}(\mathrm{P}<0.05)$. The inhibition rate of ACC-M cells was increased with increasing concentrations of GAA and time (Tables 1 and 2). The $\mathrm{IC}_{50}$ values of ACC-M cells treated with GAA for 24,48 , and $72 \mathrm{~h}$ were $33.20,15.50$, and $8.60 \mu \mathrm{M}$, respectively, and the $\mathrm{IC}_{50}$ values of HFL-1 cells were $35.13,28.00$, and $26.80 \mu \mathrm{M}$.

\begin{tabular}{|c|c|c|c|}
\hline \multirow[t]{2}{*}{$\mathrm{GAA}(\mu \mathrm{M})$} & \multicolumn{3}{|c|}{ Inhibitory rate (\%) } \\
\hline & $24 \mathrm{~h}$ & $48 \mathrm{~h}$ & $72 \mathrm{~h}$ \\
\hline 10 & $1.78 \pm 0.021$ & $2.22 \pm 0.035$ & $2.52 \pm 0.021$ \\
\hline 20 & $11.55 \pm 0.203^{\Perp}$ & $26.78 \pm 0.432^{\Perp}$ & $51.42 \pm 0.674^{\star}$ \\
\hline 30 & $46.49 \pm 0.198^{\mathbf{\Delta}}$ & $58.10 \pm 0687$ & $62.62 \pm 0.852^{\Delta}$ \\
\hline 40 & $60.09 \pm 0.850$ & $59.14 \pm 0.870$ & $63.50 \pm 0.804$ \\
\hline 50 & $59.91 \pm 0.812^{\mathbf{A}}$ & $59.26 \pm 0.657$ & $63.15 \pm 0.662^{\star}$ \\
\hline
\end{tabular}


Table 2. Inhibition rate on the proliferation of HFL1 cells treated with different concentrations of GAA for 24-72 h (\%) (means $\pm \mathrm{SD}, \mathrm{N}=3)$.

\begin{tabular}{|c|c|c|c|}
\hline \multirow[t]{2}{*}{$\mathrm{GAA}(\mu \mathrm{M})$} & \multicolumn{3}{|c|}{ Inhibitory rate (\%) } \\
\hline & $24 \mathrm{~h}$ & $48 \mathrm{~h}$ & $72 \mathrm{~h}$ \\
\hline 10 & $5.38 \pm 0.062$ & $2.44 \pm 0.033$ & $3.76 \pm 0.047$ \\
\hline 20 & $16.29 \pm 0.203^{\Delta}$ & $16.08 \pm 0.263^{\Delta}$ & $16.15 \pm 0.275^{\star}$ \\
\hline 30 & $31.40 \pm 0.417$ & $53.85 \pm 0.653^{\Delta} \square$ & $43.98 \pm 0.319 \Delta$ \\
\hline 40 & $48.82 \pm 0.434$ & $62.06 \pm 0.845^{\mathbf{\Delta}}$ & $58.72 \pm 0.746^{\boldsymbol{\Phi}}$ \\
\hline 50 & $51.85 \pm 0.378^{4}$ & $65.09 \pm 0.646^{\mathbf{\Delta}}$ & $58.66 \pm 0.656^{\mathbf{\Delta}}$ \\
\hline
\end{tabular}

\section{Apoptosis of ACC-M cells promoted by GAA}

Double-staining with annexin V-FITC/PI and fluorescence correlation microscopy analysis showed that the apoptosis of ACC-M cells was significantly increased after treatment with GAA $(10,20,30$, and $40 \mu \mathrm{M})$ for $72 \mathrm{~h}$ compared with the control group $(\mathrm{P}<0.05$; Figures 1-6); there was no significant difference in the total apoptosis rate at concentrations of $40-50 \mu \mathrm{M}(\mathrm{P}>0.05)$.

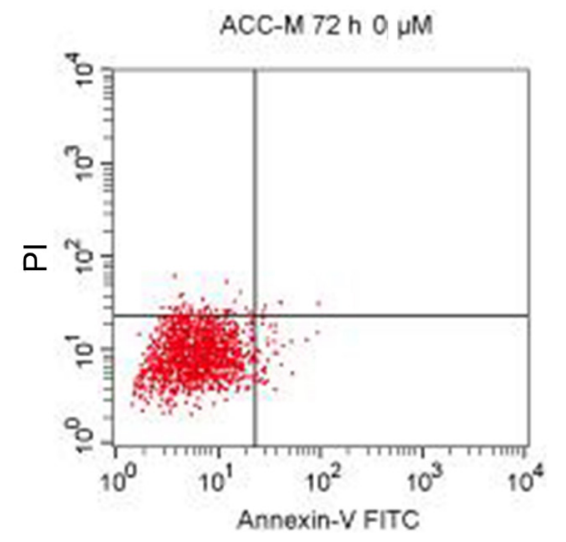

Figure 1. ACC-M cells treated with $0 \mu \mathrm{M}$ GAA for $72 \mathrm{~h}$.

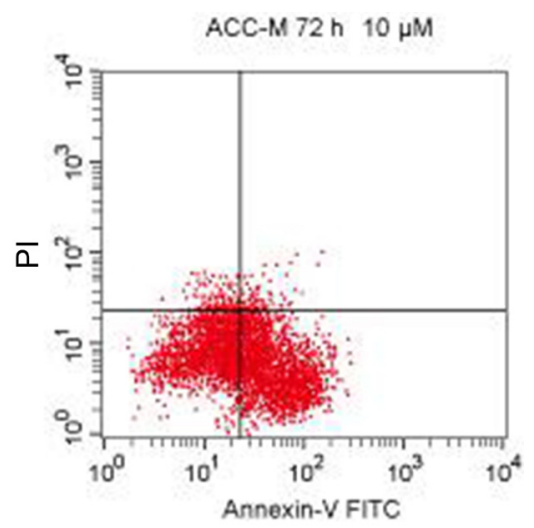

Figure 2. ACC-M cells treated with $10 \mu \mathrm{M}$ GAA for $72 \mathrm{~h}$. 


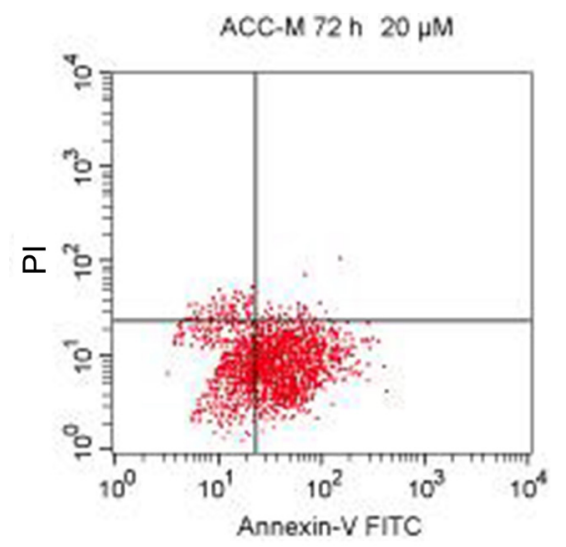

Figure 3. ACC-M cells treated with $20 \mu \mathrm{M}$ GAA for $72 \mathrm{~h}$.

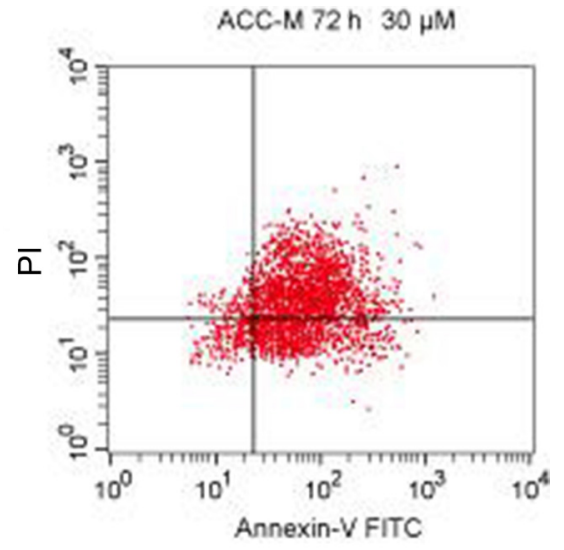

Figure 4. ACC-M cells treated with $30 \mu \mathrm{M}$ GAA for $72 \mathrm{~h}$.

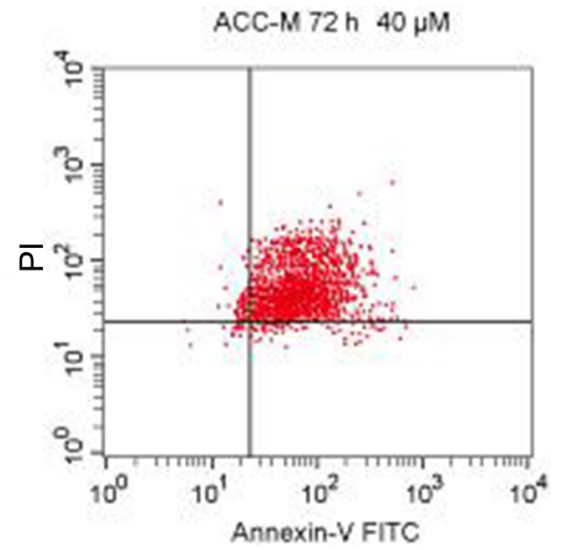

Figure 5. ACC-M cells treated with $40 \mu \mathrm{M}$ GAA for $72 \mathrm{~h}$. 


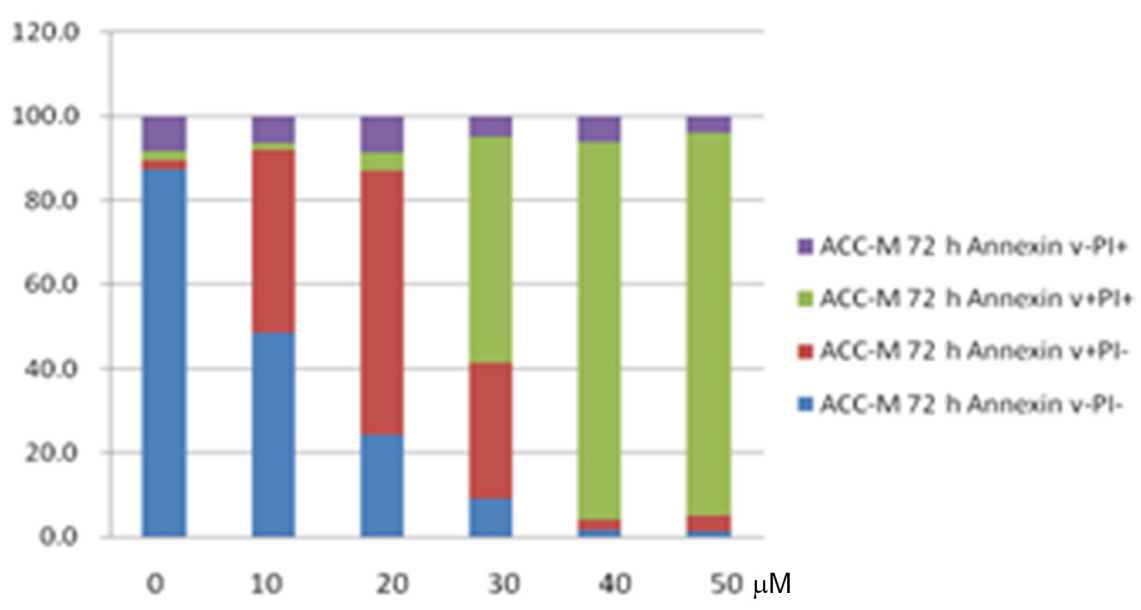

Figure 6. Apoptotic rates of ACC-M cells treated with different concentrations of GAA for $72 \mathrm{~h}(\%)$.

\section{Expression level of DNMT1 mRNA decreased in ACC-M cells treated with GAA}

The results of quantitative PCR showed that the GAA group showed a statistically significant down-regulation of DNMT1 mRNA expression in ACC-M cells treated with different concentrations of GAA for $72 \mathrm{~h}$ compared to the control group (Table 3 ).

\begin{tabular}{|c|c|c|c|}
\hline Group $(\mu \mathrm{M})$ & Ct value of DNMT1 & $\mathrm{Ct}$ value of $\beta$-actin & $2^{-\Delta \Delta \mathrm{Ct}}$ \\
\hline 0 & $25.25 \pm 0.03$ & $17.94 \pm 0.05$ & 1.00 \\
\hline 5 & $25.60 \pm 0.06$ & $17.95 \pm 0.04$ & $0.79 \pm 0.03^{\star}$ \\
\hline 10 & $25.58 \pm 0.06$ & $17.76 \pm 0.13$ & $0.70 \pm 0.03^{\Delta}$ \\
\hline 15 & $25.54 \pm 0.03$ & $17.10 \pm 0.17$ & $0.46 \pm 0.02$ \\
\hline 20 & $26.08 \pm 0.14$ & $17.33 \pm 0.18$ & $0.37 \pm 0.02$ \\
\hline 25 & $26.57 \pm 0.05$ & $17.65 \pm 0.03$ & $0.33 \pm 0.01$ \\
\hline 30 & $26.96 \pm 0.04$ & $17.33 \pm 0.03$ & $0.20 \pm 0.01$ \\
\hline
\end{tabular}

$\overline{\mathbf{\Delta}} \mathrm{P}<0.05$, compared with $10 \mu \mathrm{M}$ group; ${ }^{\circ} \mathrm{P}<0.05$, compared with $20 \mu \mathrm{M}$ group; $\cdot \mathrm{P}<0.05$, compared with $30 \mu \mathrm{M}$ group; ${ }^{\circ} \mathrm{P}<0.05$, compared with $15 \mu \mathrm{M}$ group; $* \mathrm{P}<0.05$, compared with $25 \mu \mathrm{M}$ group.

\section{DISCUSSION}

ACC is one of the most common sialaden malignant tumors, accounting for approximately $10 \%$ of salivary gland neoplasms. About $25 \%$ of adenoid cystic carcinoma cases occur in the parotid gland, while $60 \%$ occur in the minor oral salivary gland, from which palatal carcinomas are most common. ACC exhibits retarded growth, less regional node metastasis (except ACC in the root of tongue), strong infiltration of surrounding tissues, very frequent recurrence, distant metastasis, and nerve fiber encroachment in the early stage and through hematogenous metastasis, resulting in a $40 \%$ metastasis rate to the lung. Metastasis of the lung is the primary cause of patients. Because of these characteristics of ACC and its 
insensitivity to radiotherapy and chemotherapy, surgical treatment is the main therapy; local radiotherapy is currently used to improve efficacy. Thus, it is important to investigate the mechanism of tumor formation and the molecular mechanism of invasion and metastasis to develop effective treatments.

A study confirmed that gossypol plays a role in inhibiting the proliferation and apoptosis of tumor cells in vitro (Gong et al., 2009). Gossypol may inhibit growth and induce tumor cell apoptosis to achieve anti-tumor effects by damaging mitochondria directly to inhibit energy metabolism, down-regulate the expression of cell cycle regulatory proteins, inhibit protein kinase $\mathrm{C}$ and telomerase activities, intervene in signal transduction pathways, and inhibit the over-expression of Bcl-2 (Ko et al., 2007). Wang et al. (2000) detected the apoptotic peak of sub-G1 phase cells in colon cancer HT-29 and LoVo cells after treatment with gossypol by flow cytometry and found that gossypol can induce tumor cell apoptosis. Recently, the role of gossypol in anti-cancer has gained increased attention, and its killing effects on tumor cells mainly has been primarily examined in genital system tumors, such as cervical cancer (Sanli et al., 2009). It also has different killing effects against tumors in other systems, including pancreatic carcinoma, colon cancer, liver cancer, laryngeal carcinoma, lung cancer, and head and neck cancer (Balakrishnan et al., 2008, 2009; Alibaz Oner et al., 2011).

We used ACC-M cells as experimental cells and normal human fibroblasts as control cells to investigate the effect of GAA on tumor and normal cells. The results of CCK-8 showed that the inhibition rate increased with increasing concentrations of GAA and over time when ACC-M and HFL-1 cells were treated with 10-40 $\mu \mathrm{M}$ GAA for 24, 48, and $72 \mathrm{~h}(\mathrm{P}$ $<0.05)$. The $\mathrm{IC}_{50}$ values of ACC-M cells treated with GAA for 24,48 , and $72 \mathrm{~h}$ were 33.20 , 15.50 , and $8.60 \mu \mathrm{M}$, respectively, while $\mathrm{IC}_{50}$ values of HFL-1 were $35.13,28.00$, and 26.80 $\mu \mathrm{M}$. The results of double-staining with annexin V-FITC/PI and fluorescence correlation microscopy analysis showed that ACC-M cell apoptosis was significantly increased after treatment with GAA $(10,20,30$, and $40 \mu \mathrm{M})$ for $72 \mathrm{~h}$, compared with the control group (P $<0.0$ ). These results suggested that GAA played a role in inhibiting ACC-M cells and may induce their apoptosis.

Wolter et al. (2006) found that normal oral keratinocytes were insensitive to gossypol, and the $\mathrm{IC}_{50}$ value of gossypol to HNSCC cells was $4 \mu \mathrm{M}$. Oliver et al. (2004) found that the $\mathrm{IC}_{50}$ value of gossypol to normal human fibroblast was 2-10-fold higher than against HNSCCs and oral keratinocytes was 2-3-fold higher. Thus, the anti-tumor effects of gossypol were relatively specific and its inhibition effect was relatively lower in normal cells, which agrees with the results of this study. In this study, the $\mathrm{IC}_{50}$ value of GAA against HFL1 cells was higher than against ACC-M cells, which was 2 times that of ACC-M at $48 \mathrm{~h}$ and 3 times at 72 $h$. This finding supports that the anti-tumor effects of GAA were relatively specific. Another study found that gossypol showed a minimal adverse reaction and high safety. In past, its adverse reaction mainly appeared hypokalemia and damages of speratogenic epithelium of testes in some individuals when it used to be birth control for long time, which incidence rate was only about 1\% (Shelley et al., 1999). Additionally, long-term oral dose of gossypol could not induce myelosuppression (Oliver et al., 2005). A study reported that gossypol could induce an increase in aspartate aminotransferase and alanine aminotransferase, but had no significant influence on the kidneys, heart, and blood cells (Kitada et al., 2008).

The quantitative PCR results showed that DNMT1 mRNA expression was significantly down-regulated in ACC-M cells treated with different concentrations of GAA $(5,10,15,20$, 
25 , and $30 \mu \mathrm{M})$ for $72 \mathrm{~h}$ compared with the control group $(\mathrm{P}<0.05)$. With increasing GAA concentrations, DNMT1 mRNA expression gradually decreased.

DNMT1 is a key enzyme that maintains the methylation state of DNA, which is mainly catalyzed by DNMT1. The tumor suppressor gene is not methylated in normal tissues, and the methylated state cannot transcribe normally and express normal tumor suppressor proteins to inhibit tumors. Thus, the cell may proliferate monoclonally and form a tumor. This plays a critical role in tumor development in which the promoter region of the tumor suppressor gene is present in a highly methylated state and contributes to its expression silencing, which affects in the incidence and development of many malignant tumors (Esteller, 2002; Fan, 2004). Previous studies have identified numerous tumor tissues and cells, including colon cancer (Kanal et al., 2001), lung cancer (Lin et al., 2007), gastric cancer (Etoh et al., 2004), acute and chronic myeloid leukemia (Mizuno et al., 2001), myelodysplastic syndromes (Langer et al., 2005), and endometrial carcinoma (Xiong et al., 2005), in which DNMT1 expression was all upregulated. Additionally, the expression of DNMT1 in different tumors differed with clinical stage and pathological grade. Fuks et al. (2000) detected DNMT1 mRNA expression in 22 cases of endometrial carcinoma and 10 cases of normal endometrial tissues by real-time-PCR. They found that DNMT1 expression in endometrial carcinoma was significantly higher than in normal tissues $(\mathrm{P}<0.001)$. DNMT1 expression also regulated the cell cycle except for catalyzing the methylation reaction. High expression of DNMT1 may induce the cells to enter S phase and promote cell growth and proliferation (Milutinovic et al., 2003). Recent studies confirmed that a close relationship exists between the high methylation of tumor suppressor genes because of abnormal expression of DNMT1 and the incidence and development of many tumors (Luczak and Jagodzinski, 2006).

In conclusion, GAA effectively inhibited the growth and induced the apoptosis of ACC-M cells, and showed specific inhibition effects against tumor cells. Additionally, GAA decreased the expression of DNMT1 mRNA, mediating the ability of DNMT1 to methylate tumor suppressor genes in tongue cancer, which may be one of the anti-tumor mechanisms of GAA. Thus, gossypol may be a new type of demethylated anti-tumor drug, and its mechanism requires further analysis.

\section{Conflicts of interest}

The authors declare no conflict of interest.

\section{ACKNOWLEDGMENTS}

Research supported by the National Natural Science Foundation Emphases Item of China (\#81160326) and the Science and Technology Plan of Yunnan Province (\#2009CD207).

\section{REFERENCES}

Agoston AT, Argani P, De Marzo AM, Hicks JL, et al. (2007). Retinoblastoma pathway dysregulation causes DNA methyltransferase 1 overexpression in cancer via MAD2-mediated inhibition of the anaphase-promoting complex. Am. J. Pathol. 170: 1585-1593.

Alibaz Oner F, Yurdakul S, Oner E, Kubat Uzum A, et al. (2011). Evaluation of the effect of L-thyroxin therapy on endothelial functions in patients with subclinical hypothyroidism. Endocrine 40: 280-284. 
Balakrishnan K, Wierda WG, Keating MJ and Gandhi V (2008). Gossypol, a BH3 mimetic, induces apoptosis in chronic lymphocytic leukemia cells. Blood 112: 1971-1980.

Balakrishnan K, Burger JA, Wierda WG and Gandhi V (2009). AT-101 induces apoptosis in CLL B cells and overcomes stromal cell-mediated Mcl-1 induction and drug resistance. Blood 113: 149-153.

Esteller M (2002). CpG island hypermethylation and tumor suppressor genes: a booming present, a brighter future. Oncogene 21: 5427-5440.

Etoh T, Kanai Y, Ushijima S, Nakagawa T, et al. (2004). Increased DNA methyltransferase 1 (DNMT1) protein expression correlates significantly with poorer tumor differentiation and frequent DNA hypermethylation of multiple CpG islands in gastric cancers. Am. J. Pathol. 164: 689-699.

Fan CY (2004). Epigenetic alterations in head and neck cancer: prevalence, clinical significance, and implications. Curr. Oncol. Rep. 6: 152-161.

Fuks F, Burgers WA, Brehm A, Hughes-Davies L, et al. (2000). DNA methyltransferase Dnmt1 associates with histone deacetylase activity. Nat. Genet. 24: 88-91.

Gong P, Wang YL, Jiang L, Tang H, et al. (2009). Study on the effect of gossypol combined with radiotherapy in inducing apoptosis of human cervical carcinoma HeLa cells. Tumor 29: 838-841.

Hu ZY, Zhu XF, Zhong ZD, Sun J, et al. (2008). ApoG2, a novel inhibitor of antiapoptotic Bcl-2 family proteins, induces apoptosis and suppresses tumor growth in nasopharyngeal carcinoma xenografts. Int. J. Cancer 123: 2418-2429.

Kanal Y, Ushijima S, Kondo Y, Nakanishi Y, et al. (2001). DNA methyltransferase expression and DNA methylation of CPG islands and peri-centromeric satellite regions in human colorectal and stomach cancers. Int. J. Cancer 91: 205-212.

Kitada S, Ktrss CL, Krajewska M, Jia L, et al. (2008). Bcl-2 antagonist apogossypol (NSC736630) displays single-agent activity in Bcl-2-transgenic mice and has superior efficacy with less toxicity compared with gossypol (NSC19048). Blood 111: 3211-3219.

Ko CH, Shen SC, Yang LY, Lin CW, et al. (2007). Gossypol reduction of tumor growth through ROS-dependent mitochondria pathway in human colorectal carcinoma cells. Int. J. Cancer 121: 1670-1679.

Langer F, Dingemann J, Kreipe H and Lehmann U (2005). Up-regulation of DNA methyltransferases DNMT1, 3A, and 3B in myelodysplastic syndrome. Leuk. Res. 29: 325-329.

Lin PK, Hus HS, Chang JW, Chen CY, et al. (2007). Alteration of DNA methyltransferases contributes to 5' $\mathrm{CpG}$ methylation and poor prognosis in lung cancer. Lung Cancer 55: 205-213.

Luczak MW and Jagodzinski PP (2006). The role of DNA methylation in cancer development. Folia Histochem. Cytobiol. 44: 143-145.

Milutinovic S, Zhuang Q, Niveleau A and Szyf M (2003). Epigenomic stress response. Knockdown of DNA methyltransferase 1 triggers an intra-S-phase arrest of DNA replication and induction of stress response genes. $J$. Biol. Chem. 278: 14985-14995.

Mizuno S, Chijiwa T, Okamura T, Akashi K, et al. (2001). Expression of DNA methyltransferases DNMT1, 3A, and 3B in normal hematopoiesis and in acute and chronic myelogenous leukemia. Blood 97: 1172-1179.

Oliver CL, Bauer JA, Wolter KG, Ubell ML, et al. (2004). In vitro effects of the BH3 mimetic, (-)-gossypol, on head and neck squamous cell carcinoma cells. Clin. Cancer Res. 10: 7757-7763.

Oliver CL, Miranda MB, Shangar YS, Land S, et al. (2005). (-)-Gossypol acts directly on the mitochondria to overcome Bcl-2 and Bcl-X(L)-mediated apoptosis resistance. Mol. Cancer Ther. 4: 23-31.

Peng DF, Kanai Y, Sawada M, Ushiima S, et al. (2006). DNA methylation of multiple tumor-related genes in association with overexpression of DNA methyltransferase 1 (DNMT1) during multistage carcinogenesis of the pancreas. Carcinogenesis 27: 1160-1168.

Sanli UA, Gorumlu G, Erten C, Gul MK, et al. (2009). Targeting apoptosis in the hormone and drug resistant prostate cancer cell line, DU-145, by gossypol/zoledronic acid combination. Cell Biol. Int. 33: 1165-1172.

Shelley MD, Hartle YL, Fish RG, Groundwater P, et al. (1999). Stereo-specific cytotoxic effects of gossypol enantiomers and gossypolone in tumour cell lines. Cancer Lett. 135: 171-180.

Wang X, Wang J, Wong SC, Chow LS, et al. (2000). Cytotoxic effect of gossypol on colon carcinoma cells. Life Sci. 67: 2663-2671.

Wolter KG, Wang SJ, Henson BS, Wang S, et al. (2006). (-)-Gossypol inhibits growth and promotes apoptosis of human head and neck squamous cell carcinoma in vivo. Neoplasia 8: 163-172.

Xiong Y, Dowdy SC, Xue A, Shujuan J, et al. (2005). Opposite alterations of DNA methyltransferase gene expression in endometrioid and serous endometrial cancers. Gynecol. Oncol. 96: 601-609.

Yue WY, Chen WF, Fu S and Wu Y (2014a). Effects of gossypol acetic acid on DNA methylation level and mRNA expression of pl6 gene in human adenoid cystic carcinoma ACC-M cells. Kunming Yike Daxue Xuebao 35: 17-20. 
Yue WY, Chen WF, Fu S and Wu Y (2014b). Influence of gosspol acetic acid on the growth of ACC-M and methylation of E-cadherin. Kou Qiang Yi Xue Yan Jiu 30: 201-204.

Zhang M, Liu H, Guo R, Ling Y, et al. (2003). Molecular mechanism of gossypol-induced cell growth inhibition and cell death of HT-29 human colon carcinoma cells. Biochem. Pharmacol. 66: 93-103. 